\title{
The Impact of Team Management on the Organizational Performance in Bahrain Government Sector
}

\author{
Mohamed Hasan* \\ Ahlia University, Manama, Bahrain \\ E-mail: m.7asan89@gmail.com \\ *Corresponding Author
}

\author{
Ahlam Hassan \\ Ahlia University, Manama, Bahrain \\ E-mail: aahassan@ahlia.edu.bh
}

Received April, 2021; Accepted September, 2021

\begin{abstract}
Bahrain government sector organizations have started to realize the significance of team management and how it can be managed effectively and efficiently to ensure enhancing the organization's performance. The use of team management to enhance organizational performance in the Bahrain government sector has become a serious situation for the government in the Kingdom of Bahrain. However, in spite of the increasing number of studies relating to team management in developed countries, few studies have been made in the same context within gulf countries. The aim of this study is to determine how the factors of team management can affect the performance of government organizations in the Kingdom of Bahrain. The study adopted a quantitative method approach for the purpose of the study. The sample size of the study is selected from Bahrain government sector organizations, data were collected from 150 respondents, and the sample was selected based of those who were working for the government and semigovernment organizations from the employees who are representing the basics of the organization to the managers who are the responsible persons of team's formation. The generated data from the government and semi-government organizations were analyzed using many statistical tools, we used the Correlation analysis to test the relationship between our variables and Linear Regression was to test the hypothesis of the study. The results showed that only team decision has a significant positive influence on organizational performance in Bahrain government sector. However, the study result showed that there is no influence on organizational performance in the Bahrain government sector from team trust, team motivation, team cohesiveness, and job satisfaction. Finally, the study recommended the need for Bahrain government sector organizations to give full attention to team management in those organizations in which this will reflect the organizational performance positively.
\end{abstract}

Keywords: Team Management; Organizational Performance; Bahrain; Government Sector.

Type: Research paper

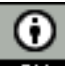

EY This work is licensed under a Creative Commons Attribution 4.0 International License.

DOI: 10.51325/ijbeg.v4i3.50

\section{Introduction}

In the last years, organizations start to realize the significance of team management and how can team management affect the organizational performance effectively and efficiently to ensure the perfect running of the organization. This may struggle to the fact that the top management teams have no single or fixed set of tasks in light of the shifting nature of work they perform (by Wageman\& Hackman, 2010). The importance of teams is very crucial in the last years since it is determining the performance of the team. "The use of teams has been ubiquitous and increasingly critical in contemporary organizations" (Gupta., 2010). Team management is defined as all about the abilities of an individual or 
an organization to lead and control a group of individuals to perform a task. Team Management also involves teamwork, communication, controlling, objective setting and performance determinate (Gulati 2009). A team is a group of people organized to work together. In addition, Team leader is someone who provides direction, instructions and guidance to a group of individuals, who can also be known as a team, for the purpose of achieving a certain goal. An effective leader will know her team members strengths, weaknesses, and motivations. (Gigili 2012)

In this research we will identify the impact of team management on organizational performance in Bahrain government sector, the government employee nowadays is struggling with challenges to enhance to government organizations performance. So, it must be able to deal with the teamwork on a perfect way to achieve the organizational goal by targeting the highest performance. Since the independence of the Kingdom of Bahrain in 1971 and issuing of the first independent government H.R.H Prime Minister Sheikh Khalifa bin Salman Al-Khalifa and it was hired and supported by HH Sheikh Isa Bin Salman Al-Khalifa may god have mercy on him, several managers has been hired by The Prime Minister to manage the government organizations and directorates. In around 45 years a lot of mentalities came on and take the lead in the government ministries in order to achieve the organizational goal (which is the governmental goal).Each type of those managers had his own organizational behavior and habits which affect the team's performance in all the ways (positively or with no influence). The government of Bahrain contains more than forty Ministries and Semi-government authorities which follow the rule and regulations of the government from a different basis. For employee's rules and regulations, the government authorities follow the CSB (Civil Service Bureau), the authority that carries on the Human Resources rules for the government of Bahrain and supervised all ministries in Bahrain from a Human Resource basis. From the financial matter, Ministry of Finance has the responsibility to manage the government financial situation. It is also related to managing the ministries budgets, projects and payments referred to an official financial Standard manual which was issued by Ministry of Finance to organize all the government treatments and any contravention for this manual will take it owner to accountability by NAC (National Audit Court). Team Management job in any government authority is complex and not that easy since you are assigned to face the different types of people that working in the government sector. In these difficult conditions, effective team management is needed in order to know how to handle those multi situations. Nowadays, the government authorities are focusing on teamwork as a practical and capable style to give a push to the organizational performance and maximize it.

However, there are many organizations that still have barriers in team management, especially the gaps between the teams. Today when we look at the difference between the member's teamwork nowadays and before more than 20 years. There will be a huge variance between them in different ways that affect the employee's effort. The government of Bahrain took in their mind this issue and established a good strategy to develop the ways of team management in public organizations. Issuing BIPA (Bahrain Institute of public Administration ) in 2006 was one of great steps by the government of Bahrain to promote the team members to an expert level of team management and develop the employees performance and behaviors by issuing many training programs which was handled by a professional coaches from Bahrain and different countries to enhance the government authorities performance from all the point of views by targeting the managers, team leaders and employees in several training courses and programs to develop their performance and strengthening them in their jobs. In another word, dealing with different types of team leaders is hard for the employees especially in government sector 
environment which might be harder than any other environment. but each team have its ups and downs, positive and negative behaviors and the smart team leader who can hide those defects and focus on the performance of the department or the organizations. In the other hand, clever team members are those who can deal with situations in a perfect way and continue performing excellently even if they faced several obstacles.

\section{Research problem:}

Team Management is not being managed and taken in an appropriate and efficient basis. This creates a huge risk since the bad team management and the ways that employees are dealing inside the teams may lead the organization to fail. Effective team management is recognized as a critical tool for sustaining competitive advantage and the government of Bahrain began to focus on how to create a good working environment by assessing the team leaders and members (employees) in government organizations. The problem of the study is about the gaps and variances on team management basis in Bahrain government sector organizations and the way applied in affecting these organizations performance. This problem becomes a significant issue for the government organizations employees because the teams are facing daily circumstances which need their high performance to be reflected in the overall organization.

This research paper is aiming to determine how the factors of team management can affect the performance of the government organizations.

\section{Literature review}

Today's government needs to be just as innovative, flexible, and responsive to business and other sectors, because "above all else, today's environment demands organizations and leaders who can respond creatively to the challenge of change" (Siegel 1996). The governments nowadays are living in the competitive world, to run the governments in a right way it should have creative managers, leaders, and teams. In the last years, organizations start to realize the significance of team management and how can team management affect the organizational performance effectively and efficiently to ensure the perfect running of the organization. The importance of teams is very crucial in the last years since it is determining the performance of the organizations. "The use of teams has been ubiquitous and increasingly critical in contemporary organizations" (Gupta al. , 2010). Gupta mentions that in the last year's team management becomes an important tool in the organization's performance improvement. Nowadays, the changes in team member's knowledge and how they think to demand a good contemporaneous with team management concept. Many authors have written about the use of teams as a critical matter in the organizations. The use of teams has been ubiquitous and increasingly critical in contemporary organizations (Mathieu et al., 2008; Gupta et al., 2010). There are three characteristics identified by Dyer (1977) that high-performance teams cooperate with other effective organizations which are: The first identification is the ability to gather data. Secondly, the ability to make sound free and informed decisions and the third one are the ability to implement those decisions with commitment. However, Blanchard and Carew (1996) developed on Dyer's list and they have identified seven characteristics of highperformance teams as listed below:

- A sense of common purpose.

- Empowered team members.

- Open communication.

- Flexibility and fluidity. 
- High productivity.

- Recognition/appreciation of individual's and the team's efforts.

- High morale.

The authors dispute that productivity and morale are the highest considerable characteristics.

Wheelan (1999) has also implemented and developed a list of characteristics of high-performance teams based on her research. The characteristics include the following:

- Agreement on goals.

- Clarity on member role assignments and expectations.

- Interdependence of members.

- Adaptive, or situational, leadership style of team leader.

- Open communication and feedback.

- The importance of discussion, decision-making, and planning.

- Implementation of team decisions.

- Norms relative to performance, quality, and success.

- Minimum membership.

- Cohesiveness and cooperative attitude.

Wheelan (1999) characteristics are similar to Blanchard and Carew (1996). There is the mutual advantage of these characteristics of high-performance teams is the decision making. A significant requirement to create a cohesive team is in creating a sense of responsibility towards the team members and this should be encouraged by the managers or the persons whom responsible for the leadership in the organization. The team members have to share a common vision of superiority in outcomes. The leadership in the organization also needs to motivate the team members essentially in the face of distresses and intensity.

\section{Organizational Performance}

Team performance is defined as the extent to which a team accomplishes its goal or mission (Devine and Phillips 2001). Team performance might be evaluated qualitatively or quantitatively according to steady work result. Another approach is that team members' psychological cognition that is team member's satisfaction for cooperation and working substantially across team goal. Of these two dimensions of team performance-related aspects, the former is associated with the recognition of team members or team leader (Stewart and Barrick, 2000), or with another objective indicator like cost reduction and production, while the latter such as job satisfaction, team commitment, or cooperation satisfaction is based on behavioral and results-oriented criterion (Kirkman and Rosen, 1999; Nathan et al. , 1991). Applying the organization objectives through team management has been used effectively; it also enhances the ability of the organization to face the hard tasks that can be achieved through the cooperation of the team. "The use of teams can be an appropriate means to accomplish objectives when the organization faces complex tasks that can best be achieved through two or more individuals cooperating towards task completion" (Wegge, Schmidt, \& Hoch, 2000). Finkelstein, Hambrick, and Cannella (2009) linked the team management with executive management as a primary decider to enhance the organizational outcomes. They define executives as "first and foremost, careful and comprehensive deciders of major courses of action." Since these primary deciders are believed to have a big influence on firm's performance outcomes, researchers have been trying to explore all possible relationships among the characteristics of top executives, their strategic choices, and organizational outcomes. We can see that this theory would argue the previous section theory for the self-managed work teams which was published by (Yang and Guy 2004). 
For example, to prepare a disaster plan, a local government must coordinate the capacity, skills, and resources of first responders and link them with agencies at other governmental levels, such as the federal Department of Homeland Security, the department that is related to keeping the USA safe from the threats that they may face. Foremost among innovations in teams and teambuilding are self-managed work teams. The added discretion and autonomy of self-management raise interesting questions (e.g., Cohen and Bailey 1997; Cohen and Ledford 1994; Cohen et al. 1996; Cordery et al. 1991; Goodman et al. 1988; Kirkman and Shapiro 2001; Klemic 1999; Manz and Sims 1993; Osborne et al. 1992; Spreitzer et al. 1999; Yang and Guy 2004; Yeatts et al. 1996). However, self-managed team works and their success in public organizations in Bahrain need to be proved in that research since there is a lack of information in that area. Recently, there has been increasing interest in their applications in public agencies. Yang and Guy (2004) surveyed American municipalities and found that $28 \%$ of all cities with populations of 50,000 or more were using them. Among these, $80 \%$ of the city managers who reported that they used self-managed work teams reported that they did so to improve productivity. If we compared Bahrain government sector to the U.S example, there are many barriers that the employees (teams) might encounter with before acquiring a selfmanage work team especially the decision making without referring to the top management, this part must be showed and presented in the results of that study. Team effectiveness is the ability of the team to meet the goals and objectives of the organizations in order to reach the organizational goals. Many models have been given by the researchers over the years to measure the team effectiveness. "Michael Lombardo and Robert Eichinger developed the famous T7 Model in 1995 to represent the factors that measure the team effectiveness. The internal factors are Thrust, Trust, Talent, teaming skill, Task Skills and external factors are team leader fit, team support from the organization." (De Meuse, 2009). Team performance is not simply a matter of having more leaders. It also matters whether or not the leaders see each other as leaders" (Feng 2011). Individual contribution mostly relates to the commitment of team member lead to the performance of organization and team outcomes (Seung-hee, Xiaojing, \& Magjuka, 2008). If team members have various ideas in a complex situation, that can help to enhance the team effectiveness and resolved the issues between team members (Pirola et al., 2004). The authors mentioned that the initiatives and the actions by the individuals in the teams are like tools to increase the team outcomes especially when there are sophisticated situations that create a good opportunity to be creative. Performance measurement became popular among the local governments of the United Kingdom in the early 1980s for five reasons, including pressure from the central government; greater public expectations and consumerism; compulsive competitive tendering (contracting to provide local government services); changing culture and attitudes among local government managers; and loss of confidence in government (Ghobadian \&Ashworth, 1994). Another reason quoted was pressure from the British Audit Commission (Ghobadian \& Ashworth, 1994). According to the Canadian Auditor General publishes an annual performance measurement report comparing municipal services such as police, fire control, social services, and libraries (Auditor General of Canada, 1997). Organizational performance is a (Nutt and Backoff, 1995) defined in this study as: a complex of how the organization accomplishes its work, i.e., the efficiency of its internal operations in converting inputs into outputs and; its overall effectiveness, or adaptability and responsiveness to its external and internal environments, including its ability to anticipate, prioritize and adapt to multiple stakeholder concerns, and to formulate and implement its strategies accordingly. Government organizations often have struggled with conforming, especially in terms of realizing, knowing, and determining the successful organizational performance. In 
addition, government organizations are facing large criticism from many places.(Rainey, Backoff, and Levine; 1976; Ban, 1995) in their study showed that managers in government sector tend to have major managerial barriers in rewarding systems and strictness choices. (Ban 1995) complies that constrained incentive systems to weaken the relationship between performance and application of extrinsic rewards. She refers to her study to managers who are blocked and have no authority to give the incentive to enhance organizational performance. (Deming 1996) stated that performance appraisal systems (in public and private sectors) establish bad competition among employees within the organization which affect organizational teamwork and performance. (Collins and Porras 1994) found growing evidence that internal competition has negative results to organizational performance because it activates conflict which makes the employees morale lower, increases their work stress and reducing the teamwork.

\section{Team management and decision making :}

Decision-making processes and strategy implementation in public organizations are subject to excessive interventions, interruptions, and extensive involvement of external authorities and interest groups (Rainey, Backoff, and Levine; 1976). The authors mentioned the struggles that public organizations employees are facing since there are several causes that make the decision-making processes harder. The concept here is that any chosen process by the organization to make decisions affect its ability to achieve the needed changes successfully. The decision-making process in public organizations is characterized by a limited capability to implement planned changes. Rainey (1989) explains that managers in public organizations have less independence and flexibility to make decisions. This is due to governmental barriers and external political impacts.

Rainey (1989) stated that boundaries and processes often constrain:

- Managerial authority to act independently.

- $\quad$ Senior executives are reluctant to delegate authority.

- $\quad$ Reliance on formal regulations is used to control the behavior and actions of lower level managers and employees.

Larson and LaFasto (1989) set the principles of trust and collaborative environment as being important for teamwork. These principles of trust and collaboration structure on the humanness of the workers. Those two principles would encourage employees to feel they are valued because they are given responsibilities and trusted because they are given the necessary freedom to make decisions" (Larson \&LaFasto, 1989, pp. 126-127). Zajac and AlKazemi (1997) contend also that teams would be useful in the government, but first "they must be entrusted by organizational executives with the scope of organizational authority and resources that will allow them to take effective action". However, (Betts 2004) stated that leadership is not only about people but also the establishment of processes and proper decision-making procedures. In addition, public sector authorities might struggle to activate the basics approaches to decision making since it is a substantial factor to get a good organizational performance. Government organizations sound to be making at least the effort to empower their employees and involve them in taking major decisions. Dursk and Newell (1999) stated that " over half of the government agencies that reinvented themselves claimed employee involvement in the process". 


\section{Team management and job satisfaction}

In government, as in morality, the hardest of things to make is progress (Wilson 1887).Emmert and Taher (1992) assigned the lack of awareness to research on public employees. Further cloning illicit without authorization. Given the unique function public sector employees perform in policy figuration and implementation, there is a huge need for the employees to understand the job behavior and attitudes we know relatively little about public sector professionals, particularly the character of their work attitudes and motivation (Emmert and Taher 1992, p38). In fact, Ting (1997) contend that the amount of research on the job satisfaction of government employees still weak. De Leon and Taher (1996) found that local government employees in Colorado, the USA took high job satisfaction. They further noted substantial rewards, such as the chances for development, safely correlated with the levels of satisfaction. However, the 45thVice President of USA Albert Gore's stated that the government is full of good people trapped in a bad system rings of concern for employee satisfaction (Gore 1994). An organization can utilize the employees' drives to achieve its own objectives by first determining what the employees need, and then making the satisfaction of their needs contingent on behaving the way it wants them to behave (Heffron 1989). It becomes necessary to measure the public service motives in the context of "a type of human need" (Wise 1999). More than thirty years ago, Paine, Carroll and Leete (1966) and Rhinehart and his collaborators (1969) stated that groups of business managers showed a higher job satisfaction than public managers. In addition, Lachman (1985) also found greater levels of job satisfaction between CEOs in the private sector than high-ranking public managers since the CEO's in the private sector are compared with the Undersecretaries in the public sector. Blund and Spring (1991), examining levels of job satisfaction for the master of public Administration graduates who took a place in the public, private sectors through a survey questionnaire, they found that their sample respondents reported higher satisfaction with salaries and promotions opportunities in the private sector rather than the public sector.

\section{Team management motivation:}

Carrison (2011) mentioned that public sector employees in the USA need to be more closely supervised and held accountable in order to get the most out of them. The author said that the government employees in the United States need to be supervised and headed closely by someone else in order to get the maximum performance from them.

The Korean Experience in motivation:

A study which has been made by Choi (2001) about the Korean experience in public argued that public managers showed lower levels of job involvement than private managers. Thus, public service motivation was at very low level (1975).

Wittmer (1991) tried to grab the devious meaning of public sector motivation using the reward preference approach. He used a survey method and his result was the managers in public and hybrid organizations preferred being helpful to others and engaging in community service while managers in private organizations preferred higher pay and status and prestige. He confirmed these dissimilarities with the title "Serving the People or Serving for Pay" (Wittmer 1991, p 369).

However, many experts disputed that employee's motivation should be more predominant in the public sector (Perry and Wise 1990, Crewson 1997, Wise 1999) since government should avail the public interest on a direct basis.

The theorists also argue that government can do nothing right (Todaro1996), because of the faith that economic efficiency reflected to be the public eventual target, it can be obtained through competitive markets and profit based motive systems. 
In sum, public employees have been described as being dangerous manipulators of political power, intolerable oppressors of the individual, or bungling, poor performers (Goodsell 1983) since there is a nonstop blames to their laziness and idleness.

Team cohesiveness:

Hung (2003) in his study about Taiwanese national basketball team defined team cohesion is critical for the success of the team .

The higher cohesion in a group, the greater the member adherence to the group goals and the group achieve more outcomes (Robbins, 1997). Anshel (1990) also expressed that higher cohesion teams tend to be more communicative with each other, individual is compatible with the team leader and manager, and the team goal is reflected in a good manner.

However, Shanley and Langfred (1998) stated in their study about work group cohesiveness in U.S government sector that public sector organizations face continued waves of budget cuts, downsizing and reductions in force, managers should be aware of the potential benefits of keeping cohesive work among the teams together where possible.

In addition, team or group leaders in these organizations must manage their teams more carefully than ever before. The changes in public sector organizations might extremely increase the cohesiveness of teams as responses to external threats and common doubts and this will boost the cohesiveness among the teams. Studies on cohesiveness emerged from the definition by Festinger's (1950), which underlined the dimensions of the three forces of cohesiveness: task work, teamwork, and group identity). Finally, the team conflict may increase the cohesiveness between the team members but at the same time ,it may decrease the performance of that team as team members become busy with discrepancy rather than coordination between each others.

\section{Team management and Trust:}

Most studies recommend that some individual characteristics, personal attributes or hostility are related with trust (Brown, 2004). Trust brings the positive conduct with the other team member and builds the relationship for the achievement of the defined goals (Camerer, Sitkin, Burt \& Rousseau, 1998). In the presence of trust team members performs their tasks smoothly, effectively, and economically which reduce the cost and time factor and to get the desired outcomes with the help of sharing knowledge ideas (Grant 2004). In the government organizations, since the most volume of decisions are coming from the top management, there might be a lack of trust in some ways. This should be identified in that research to know the amount of trust that given by the top management to the team members. In view of the present study, trust is integrated with constant and communication and continual interpersonal interaction to build the loyalty and willing to the work with team members (Wilson \& Straus, 2006). Mostly Researchers suggested that if task interdependence has existed in organizational structure or different nature of departments, mutually dependent structure provide the better coordination among the team members who will be working in the different department and perform the various task in a deliberate arrangement of any organization (Brown, 2003; Gillespie \& Mann, 2004). A study that made in the government of Malaysia (Jain, Sandhu, Goh 2014) enhanced the findings from past research (Chowdhury, 2005; Lee et al., 2006; Huang et al., 2008). They stated that both affective and cognitive trust are important factors to influence trust and knowledge sharing attitude. Zand's (1972) notice from administrative decision-making teams that trust shown by team members is linked with directness and accuracy of information. Managers and team leaders in the government of Malaysia face a significant issue of planting trust into their team members. Even though, if the team is not building trust relationships we cannot call it an effective team since it failed to share 
the trust and knowledge between the team members. Managers and team leaders should militate for a teamwork environment that is helpful to both professional and social collaboration. "An environment of cooperation should be promoted by the managers. Team-based performance evaluation could have the possibility to start an environment where people can rely on one another (Cianni and Wnuck, 1997)". "Team-based performance evaluation is suggested to be effective for work that requires resource sharing close coordination and trust for one that contributes to a common fate (Becker and Mathieu, 2003)".

\section{Research Hypotheses:}

The following hypotheses will be defined in this research in order to answer the research question:

$\mathrm{H}_{1 \mathrm{a}}$ : Team decision positively influences organizational performance in Bahrain government sector.

$\mathrm{H}_{2 \mathrm{a}}$ : Team motivation positively influences organizational performance in Bahrain government sector.

$\mathrm{H}_{3 \mathrm{a}}$ : Team trust positively influences organizational performance in Bahrain government sector.

$\mathrm{H}_{4 \mathrm{a}}$ : Team cohesiveness positively influences organizational performance in Bahrain government sector.

$\mathrm{H}_{5 \mathrm{a}}$ : Job satisfaction positively influences organizational performance in Bahrain government sector.

\section{Research Methodology}

Since the subject of this study is related to team management and organizational performance public sector, the most suitable population will cover Bahrain government sector organizations, attracting those who occupy a position like: Managers, head of departments, Unit heads, seniors and any equivalent positions as well as employees who mainly are responsible and accountable for the organization's performance and its outcome. Only the organizations that consider a government or semi-government organization and clearly identified in public organizations profile were selected, other organizations such is any organization in the private sector were ignored. More than 15 organizations were reviewed. However, the population size for 15 organizations found as more than 2000 employee who was matched with targeted population since this study targeted the whole government and semi-government employees.

\section{Study Population and Sample:}

The sample size of this study is determined by Bahrain government sector organizations, the sample had to accomplish selecting criteria and shows the population, as it should consider one from Bahrain government sector organizations. Then, the respondents should have worked in the area of government and have been introduced in team management and taking the responsibility of their jobs and they must be accountable for their organization performance. Those who are most suitable and involved people for such research and they can provide information for the study. The appropriate sample size for this study are 112 employees with $92.3 \%$ confident level, this would give a fair representation of the population. The questionnaires were distributed among 150 employees working in government or semi-government sector organizations, a total of 120 questionnaires were received back. However, eight out of 120 responses were 
identified as invalid and inaccurate since there are several reasons behind them so they were excluded, some parts were missing, many questions have double or more answers. So, the responses for this questionnaire were 112 which will give a response rate of $74.67 \%$.

\section{Data collection methods - research instruments:}

This section is indicating the used techniques in collecting the data of this research. Data collection includes getting the data in accordance with the research design which appointed earlier. However, the nature and the scope, as well as the object of the inquiry, is substantial since it will affect the choice of the method. After choosing the method, time is also considered as a crucial factor. Two sources of data collection are involved in the research design, primary and secondary. Primary sources were collected through survey and secondary collected from books, previous related articles, journals reports and studies to gain knowledge and understanding the whole subject of the study. Thus, quantitative research method was used.

\section{Questionnaire design:}

The main data gathering tool for this research is the survey questionnaire, which has been discussed in previous chapters. The questionnaire was intended by the researcher based on the conceptual framework and the objectives of this research. A questionnaire will be used to gather the compile the data. Due to a general definition, a questionnaire is a research instrument consisting of a series of questions and other prompts for the purpose of gathering information from respondents. Mostly it is used in business research area due to the easiness of data transmission and treatment with the availability of different statistical software bundles.

However, questionnaire provides the researcher with a high rate of response in a short time manner. Also, it gives the opportunity to reach the information from the individuals on a direct basis if they have limited resources. Using close questions in the questionnaire makes multiple similarities easy to make. The design of the questionnaire is strongly influential in locating the quality of the data collected in research. A badly designed questionnaire might lead to misunderstanding and errors or bias on the data. However, it may disturb the participant from completing the questionnaire because he will feel bored when he do it. There are two important aspects of questionnaire design that must be taken in researcher consideration once he is in the development stage, they are questioning sequence and layout. "Questions sequence may help the researcher in several roles, such as maintain participants, collaboration and involvement throughout the questionnaire by using interesting, simple to understand and easy to answer opening questions (Zikmund and Babin 2006)" Even though,(Zikumnd and Babin 2006) mentioned that the questions sequence helps the researcher to avoid order bias which can result from a particular answer's position or questions order. Our questionnaire was designed by using a Likert scale type. Respondents of the questionnaire should answer if they agree or disagree the various items of the survey from 1 to 5:
1. Strongly Disagree.
2. Disagree.
3. Neutral Disagree.
4. Agree.
5. Strongly Agree.

The previous scales designed to consider the impact of team management on organizational performance in Bahrain government sector organizations. 
The Questionnaire has three parts:

First Part: demographic sections, which is consisting of six items determining the demographic characteristics of the questionnaire respondents.

Second Part: organization information, it will contain general questions about the organization structure.

Third Part: To assess team management in Bahrain government sector organizations. Also, several questions have been included in the questionnaire to measure the organizational performance and link it to the team management components is this research which is: Team empowerment, team decision, team motivation, team and, team cohesiveness and job satisfaction. However, the questionnaire template has been implemented, designed and tested based on published researches which have been done by many authors around the world who wrote about the above concepts and related them to team management. The distribution of questionnaire has been by using a paper approach (hard-copy) as well as an electronic approach by sending emails with encrypted file to the respondents. We proved all participants that their personal information and their responses would be a confidential matter for us. Also, all the collected data will be used for educational purpose only. We adopted the questionnaire based on six past and published experiences. Then we developed the questionnaire in order to match this research aim and objectives. First of all, team management and organizational performance aspect have been relied based on Simon, Cary Alan (1998) and his research about organizational performance in the public sector: A comparison of seventy-seven federal bureaus receiving or not receiving the president's quality award 1992-1997. United States International University, USA. The author in his research presented a different criteria's that are related to organizational performance in the government sector. The second aspect of the survey was about team decision which has been implemented based on "Billy T.W. Yu, W.M. To, Peter K.C. Lee (2012), Quality management framework for public management decision making". Their research has been studied on the public sector in China, Hong Kong, and Macau. The third aspect of the survey was team motivation. We implemented a previous survey that had been used by "Cowley and Smith (2013) Motivation and mission in the public sector: evidence from the World Values Survey". They have made a global study about motivation in the public sector which was very useful. The fourth aspect of this survey was about team trust. This aspect has been designed based on interpersonal trust measures (McAllister, 1995). The fifth aspect was about team cohesiveness. This part was based on Chidambaram cohesiveness scale (1996). The last aspect of our questionnaire was about the job satisfaction and it was implemented based on revised "Minnesota satisfaction questionnaire by (Weiss, et al., 1967)".

All the previous aspects were included in our questionnaire by following Likert scale type.

\section{Data Analysis, Conclusion, and Recommendation}

\section{Data analysis:}

This study will include and explain the result of the analyzed collected data, this research used SPSS to analyze the findings which have been obtained from the questionnaire that has been distribut ed before. The questionnaire was distributed among 150 employees working in Bahrain government sector organizations and Bahrain semi-government organizations that are under the umbrella of the government of Bahrain and following all the rules and regulation as same as the government sector organizations (ministries), a total of 120 completed questionnaires were received back. 
Eight of the 120 responses were identified as invalid due to many reasons and they were excluded. Some parts of the questionnaire were missing and some of them have double or more answers. Thus, the responses to the questionnaire were 112 and that give a response rate of $74.67 \%$. The table 1 below summarizes the respondent's profile.

Table 1: Respondents profile summary

\begin{tabular}{|l|c|}
\hline \multicolumn{1}{|c|}{ Element } & Result \\
\hline Confident Level & $92.3 \%$ \\
\hline Confidence Interval & $7.7 \%$ \\
\hline Population Size & $2000+$ \\
\hline Appropriate Sample Size Found & 150 \\
\hline Distributed questionnaire & 150 \\
\hline Respondents & 120 \\
\hline Valid Respondents & 112 \\
\hline Invalid Respondents & 8 \\
\hline Response Rate & $74.67 \%$ \\
\hline
\end{tabular}

Table 2: Means score for respondents on team decision

\begin{tabular}{|c|c|c|c|c|c|c|}
\hline & $\begin{array}{c}\text { Q6: Team } \\
\text { members } \\
\text { understand } \\
\text { their role in the } \\
\text { organization. }\end{array}$ & $\begin{array}{c}\text { Q7: Team } \\
\text { members do } \\
\text { not blame } \\
\text { others for } \\
\text { problems and } \\
\text { work together } \\
\text { to take the } \\
\text { appropriate } \\
\text { decisions. }\end{array}$ & $\begin{array}{l}\text { Q8: Team } \\
\text { members } \\
\text { accept } \\
\text { responsibility } \\
\text { for solving } \\
\text { problems that } \\
\text { are a joint } \\
\text { responsibility. }\end{array}$ & $\begin{array}{c}\text { Q9: Team } \\
\text { members seek } \\
\text { opportunities } \\
\text { to enhance } \\
\text { their } \\
\text { competence } \\
\text { and abilities to } \\
\text { take decisions. }\end{array}$ & $\begin{array}{c}\text { Q10: Team } \\
\text { members } \\
\text { share } \\
\text { knowledge } \\
\text { openly } \\
\text { between them } \\
\text { once they want } \\
\text { to take a } \\
\text { decision. }\end{array}$ \\
\hline \multirow{2}{*}{$\mathrm{N}$} & Valid & 112 & 112 & 112 & 112 & 112 \\
\hline & Missing & 0 & 0 & 0 & 0 & 0 \\
\hline \multicolumn{2}{|r|}{ Mean } & 3.5982 & 3.3036 & 3.7054 & 3.6339 & 3.6339 \\
\hline \multicolumn{2}{|c|}{ Median } & 4.0000 & 4.0000 & 4.0000 & 4.0000 & 4.0000 \\
\hline \multicolumn{2}{|c|}{ Std. Deviation } & 1.03506 & 1.21432 & 1.05385 & .98635 & 1.11497 \\
\hline \multicolumn{2}{|c|}{ Variance } & 1.071 & 1.475 & 1.111 & .973 & 1.243 \\
\hline \multicolumn{2}{|c|}{ Skewness } & -.466 & -.329 & -.793 & -.468 & -.662 \\
\hline \multicolumn{2}{|c|}{ Kurtosis } & -.396 & -.964 & .222 & -.083 & -.193 \\
\hline
\end{tabular}

\section{Conclusion:}

Based on the aims and objectives of this research which represented in chapter one, and by reviewing these study findings, this chapter will present the conclusion in the next paragraphs. The objective of this study has been accomplished and successfully achieved a conclusion which answers all research questions and added a proof and argues to the previous literature. Also, it has validated the findings of the previous studies and provides a faith on the recommendation. 
This study evaluated team management in Bahrain government sector organizations and how it would impact on the organizational performance, from the results of the study, it can be complemented that with full respect to the hypotheses and the study results that team management has a direct impact on Bahrain government sector organizations performance. In this matter, any improvement and development in the procedure related to team management will increase the performance in the organization.

The research results in this study show that not all team management factors are implemented to an equal degree in Bahrain government sector organizations, but it also shows that team management has a direct impact on overall organizational performance. The analysis of the research has shown that team management factors have a positive or no influence on the organizational performance but it is limited and depends on how those organizations are acquiring those factors. Team management is an important instrument to enhance the performance of the organization. To adjust its effectiveness, team management is a core component in improving the organizational performance.

Team management is appearing through team member's innovation and interaction. It plays a significant function in increasing the organizational performance and helps the teams in terms of decision making.

The results presented in this study show that not all team management factors are reflecting the same degree on the organizational performance in Bahrain government sector. Analysis of the data shows that team management factors positively influence the organizational performance like team decision. The other results show that there is no influence from team cohesiveness, team trust, and job satisfaction. Finding shows that the effective team decision will positively influence the organizational performance in Bahrain government sector. Team members understand the role of their organizations in Bahrain government sector since there are a manual that coordinate their job descriptions. Also, most of the employees agreed on not blaming each other for problems and work together to solve them. They accept the responsibilities to solve the problems by taking the right decision and they seek for opportunities to enhance their decision making by sharing knowledge openly between each other. Based on our hypothesis and after analyzing this study results and with a high respect to the other variables. There is no influence on organizational performance in Bahrain government sector from team trust, team cohesiveness, and job satisfaction that we mentioned in our discussion in chapter four due to various reasons if we compared them to the previous literature. Investing in developing team management factors can lead to an improvement in organizational performance. It is important to investigate the shortage in these factors and put the reliable solutions to fix it because it adds more value to the organizations. The study also explains the ability of team management factors to reach all type of employees in the organizations since the factors are applied to all of them based on a daily practice. Thus, within Bahrain government sector organizations, all level of employees are involved in team management and living its factors every day in order to boost the organizational outcome. The result of this study is consistent with past literature like (Deming 1996, Ghobadian and Ashworth 1994, Guy 2004) who stated that the team management has a significant impact on organizational performance. It also agreed with (Rainey 1989, Cooke 1994, Kim 2005, Zajac and AlKazemi 1997, Dursk and Newell 1999) that team decision is having a positive impact on organizational performance in government or public sector. However, the study had a different point of view in job satisfaction and it is diverse with (DeLeon and Taher 1996, Gore 1994) who found that public employees in the USA have a high job satisfaction which affects the organization performance positively. It is agreed with (Ting, 1997) who stated that the amount of job satisfaction still weak. The study found that there is a lack of trust in Bahrain government sector which not influence the organizational 
performance in a good manner. this made a various concept on (Jain, Sandhu, Goh 2014) who applied a study on the government of Malaysia and stated that trust is bringing a positive feeling inside the teams. In team cohesiveness, Bahrain government sector teams are suffering from the lack of cohesiveness which made no influence on the organizational performance. This study did not match with what (Robbins 1997, Anshel1990) about team cohesiveness that it reflects the team goals in a good manner. Shanley and Langfred (1998) statement is recommended for this study "organizations should manage their teams more carefully since the changes in public sector organizations may extremely increase the cohesiveness of teams as responses to external threats and common doubts and this will boost the cohesiveness among the teams". This study showed a low level of influence from team cohesiveness on organizational performance in Bahrain government sector organizations.

\section{Recommendation:}

Based on this study results, we can bring a bunch of important recommendations which targeting how to enhance the factors of team management as follows:

- Provide the team members in the organizations (all categories of employees) by several rich training courses in team management and the successful team factors, this will enhance their knowledge about team management and definitely will reflect on their own and organizational performance.

- There should be a distributed culture among Bahrain government sector organizations about team management and how it could impact the organizational performance. This should appear at the top of the government and circulate it to the whole organization.

- The management in Bahrain government sector organizations should be ready to support team management and enhance it. The team members in government organizations are wishing to create an effective team management culture and this effort requires a high support from the managers.

- Job satisfaction is one of the most important elements of team management; there should be a good level of job satisfaction within Bahrain government sector organizations.

- There should be an amount of trust between the government sector team members and their management. Trust is one of team management factors which we discussed in this research and once it is applied on the right basis it will affect the organizational performance directly, this is proofed based on other countries from the previous studies.

- There is a need to involve the employees in the process of team management strategy; since they are very important in achieving the organizational goal by making them feel their importance to their organizations.

\section{References}

Barrick, M. R., Bradley, B. H., Kristof-Brown, A. L., \& Colbert, A. E. (2007). The moderating role of top management team interdependence: Implications for real teams and working groups. Academy of Management journal, 50(3), 544-557. https://doi.org/10.5465/amj.2007.25525781 
Becker, W.S., and Mathieu, J. (2003). Team performance, in Edwards, J.E., Scott, C. and Raju, N.S.(Eds), The Human Resources Program Evaluation Handbook, Sage Publications, CA, 285-300.

Billy T.W. Yu, W.M. To, Peter K.C. Lee (2012). Quality management framework for public management decision making. School of Business, Macao Polytechnic Institute, Macao, The People's Republic of China. Hong Kong Polytechnic University, Hong Kong, The People's Republic of China.

Blanchard, K., Carlos. J. P., \& Randolf, A. (1996). Empowerment takes more than a minute. Wiley: California.

Blund, B. E., \&Spring, K. A. (1991). MPA Graduates and the Dilemma of Job Satisfaction: Does Crossing the Sector Line Make a Difference? Public Personnel Management, 20 (4),449-455. https://doi.org/10.1177/009102609102000406

Cannella Jr, A. A., Park, J. H., \& Lee, H. U. (2008). Top management team functional background diversity and firm performance: Examining the roles of team member colocation and environmental uncertainty. Academy of management Journal, 51(4), 768-784. https://doi.org/10.5465/AMJ.2008.33665310

Chidambaram, L. (1996). Relational development in computer-supported groups. MIS Quarterly, 20(2), 143-166. https://doi.org/10.2307/249476

Chowdhury, S. (2005). Demographic diversity for building an effective entrepreneurial team: is it important? Journal of Business Venturing, 20(6),727-746. https://doi.org/10.1016/j.jbusvent.2004.07.001

Cianni, M., \& Wnuck, D. (1997). Individual growth and team enhancement: Moving toward a new model of career development. Academy of Management Perspectives, 11(1), 105-115. https://doi.org/10.5465/ame.1997.9707100663

Cohen, S. G., \& Bailey, D. E. (1997). What makes teams work: Group effectiveness research from the shop floor to the executive suite. Journal of management, 23(3), 239-290. https://doi.org/10.1177/014920639702300303

Emmert, M. A., \& Taher, W. A. (1992). Public sector professionals: The effects of public sector jobs on motivation, job satisfaction and work involvement. The American Review of Public Administration, 22(1), 37-48. https://doi.org/10.1177/027507409202200103

Heffron, F. A. (1989). Organization Theory and Public Organizations: the Political Connection. Englewood Cliffs, NJ: Prentice Hall.

Hung, S. J. (2003). Organizational conflicts and responsive communication strategies: A study of a Taiwanese diplomatic organization. Unpublished doctoral dissertation, University of La Verne, California.

Kaboolian, L. (1996). How do public managers manage? Bureaucratic constraints, organizational culture, and the potential for reform. San Francisco: Jossey-Bass.

Kirkman, B. L., Rosen, B., Gibson, C. B., Tesluk, P. E., \& McPherson, S. O. (2002). Five challenges to virtual team success: Lessons from Sabre, Inc. Academy of Management Perspectives, 16(3),

https://doi.org/10.5465/ame.2002.8540322

Lachman, R. (1985). Public and private sector differences: CEOs' perceptions of their role environments. Academy of management journal,28(3), 671-680. https://doi.org/10.5465/256122

Larson, C., \& LaFasto, F. (1989). Teamwork: what must go right, what must go wrong. Newbury Park, CA: Sage.

Lee, S. H., Bonk, C. J., Magjuka, R. J., Su, B., \& Liu, X. (2006). Understanding the dimensions of virtual teams. International Journal on E-Learning, 5(4), 507-523. 
Levine, J. M., \& Moreland. (1976). Progress in small group research. Annual Review of Psychology, 41, 585-634.https://doi.org/10.1146/annurev.ps.41.020190.003101

McAllister, D. (1995). Affect- and cognition-based trust as foundations for interpersonal cooperation in organizations. Academy of Management Journal, 38(1), 24-59. https://doi.org/10.2307/256727

Paine, F. T., Carroll Jr, S. J., \& Leete, B. A. (1966). Need satisfactions of managerial level personnel in a government agency. Journal of Applied Psychology, 50(3), 247. https://doi.org/10.1037/h0023422

Samuel, E. (2004). Racism in peer-group interactions: South Asian students' experiences in Canadian academe. Journal of College Student Development, 45(4), 407-424. https://doi.org/10.1353/csd.2004.0053

Siegel, M. (1996). Reinventing management in the public sector. Federal Probation[Electronic version], 60 (1), 30-35.

Simon, Cary Alan (1998), Organizational performance in the public sector: A comparison of 77 federal bureaus receiving or not receiving the presidents quality award 19921997. United States International University, USA.

Srivastava, Mohit; Rogers, Helen; Lettice, Fiona. team performance management: past, current and future trends. Team Performance Management 19.7/8 (2013): 352-362. https://doi.org/10.1108/TPM-04-2013-0009

Straus, A., \& Corbin, J. (1990) Basics of qualitative research: Grounded theory procedures and techniques. Thousand Oaks, CA: Sage.

Ting, Y. (1997). Determinants of job satisfaction of federal government employees. Public personnel management, 26(3), 313-334. https://doi.org/10.1177/009102609702600302

Todaro, M. P. (1996). Economic Development. Reading, Mass. Addison-Wesley Publishing Co.

Wageman, R. (2010). Interdependence and group effectiveness, Administrative Science Quarterly, 40(1), 145-180. https://doi.org/10.2307/2393703

Wegge, J., Schmidt, K. H., \& Hoch, J. (2009). Goal setting: Basic findings and new developments at the team level. In Industrial engineering and ergonomics (pp. 245-254). Springer, Berlin, Heidelberg. https://doi.org/10.1007/978-3-642-01293$\underline{8} 19$

Weiss, H. M., Dawis, R. V., England, G. W., \& Lofquist, L. H. (1967). Manual for the Minnesota Satisfaction Questionnaire. Minneapolis, MN: Industrial Relations Center, University of Minnesota. https://doi.org/10.1037/t05540-000

Wheelan, S. (1999). Creating effective teams: A guide for members and leaders. Thousand Oaks, CA: Sage.

Wise, L. R. (1999). The Public Service Culture.” In Stillman, R. J. (eds.), Public Administration: Concepts and Cases. 342-353. Boston: Houghton Mifflin.

Wittmer, D. (1991). Serving the People or Serving for Pay: Reward Preferences Among Government, Hybrid Sector, and Business Managers. Public Productivity and Management Review, 14(4), 369-383. https://doi.org/10.2307/3380953

Zajac, G., \& Al-Kazemi, A. (1997). Reinventing government and redefining leadership: Implications for personnel management in government. Public Productivity \& Management Review, 372-383. https://doi.org/10.2307/3380678

Zand, D.E. (1972). Trust and managerial problem solving, Administrative Science Quarterly, 17(2), 229-239. https://doi.org/10.2307/2393957

Zikmund, W., Babin, B (2006 ). Exploring Marketing Research (9th International edition). Ohio - Thomson South Western. 